\title{
Rigid multivalent scaffolds based on adamantane
}

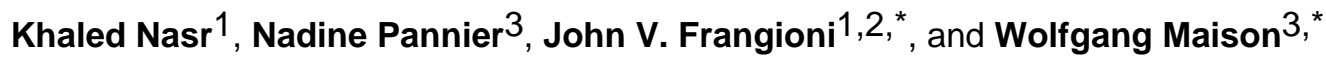 \\ 1Division of Hematology/Oncology, Department of Medicine, Beth Israel Deaconess Medical Center, SL- \\ B05, 330 Brookline Avenue, Boston, MA 02215
}

2Department of Radiology, Beth Israel Deaconess Medical Center, SL-B05, 330 Brookline Avenue, Boston, MA 02215

3Justus-Liebig-Universität Gießen, Institut für Organische Chemie, Heinrich-Buff-Ring 58, 35392 Gießen, GERMANY

\begin{abstract}
We present two new synthetic strategies to rigid multivalent scaffolds of the general structure $\mathbf{1}$ based on adamantane. Both routes start from arylated adamantane derivatives and give the target compounds 12 and 18 in 5 and 7 steps, respectively. These scaffolds have been designed for the assembly of multivalent binders for cell surface epitopes. The adamantane nucleus exposes three carboxylic acid groups in a well defined tripodal geometry for conjugation of targeting ligands. In addition, an amino group at the fourth bridgehead position provides a flexible linker for attachment of effector molecules such as contrast agents, radiotracers, or cytotoxins without interfering with the cell binding process.
\end{abstract}

\section{Introduction}

Multivalency is a common phenomenon in nature to enhance affinity and specificity of receptor ligand interactions. ${ }^{1}$ Chemists have made use of this concept in various contexts. ${ }^{2-9}$

The binding ability of multivalent agents is influenced by the number, size and orientation of the binding sites, as well as the shape, orientation and flexibility of the scaffold to which monomeric ligands are attached. Theoretically, the largest gain of binding affinity for a given ligand-receptor interaction is expected for a perfect fit of the ligands to the binding epitope. 10 A scaffold for the assembly of multivalent ligands must therefore orient the ligands in a defined and proper geometry for binding. ${ }^{11-13}$ This geometry, along with other design criteria (such as the number of ligands, solubility, biocompatibility) may vary for different applications and in consequence, a variety of different scaffolds has been used in the past. ${ }^{14-17}$

We have designed adamantyl scaffolds 2 (Figure 1) for multivalent interaction of small molecules with cell surface epitopes ${ }^{18}$ and have shown that this adamantane-based strategy can improve binding affinity by over $1.5 \mathrm{logs}$, taking a prostate-specific membrane antigen (PSMA) small molecule radiotracer from an affinity of $9 \mathrm{nM}^{19}$ to $400 \mathrm{pM}^{20}$ A special feature of these conjugates is the geometry of the bridgehead substituted adamantanes, orienting three ligands in a tripodal recognition motif and a fourth functional group for conjugation to contrast agents without interfering with cell surface binding.

Despite our encouraging results, compounds like $2(n=3)$ are not ideal scaffolds, because the propionate linkers between the adamantane nucleus and the ligands are flexible, rather than

**olfgang.maison@org.chemie.uni-giessen.de and jfrangio@bidmc.harvard.edu 
rigid. However, the synthesis of more rigid derivatives $2(n=0)$ proved to be difficult due to the unique reactivity of substituted adamantane derivatives. Other rigid scaffolds with tripodal recognition motifs have been reported and successfully used for applications in material science. ${ }^{21}$ However, these systems require rigidifying aromatic spacers and are therefore not optimal for applications in polar media.

\section{Results and discussion}

Functionalization of the bridgehead positions in adamantyl scaffolds can be achieved most reliable by radical or cationic chemistry. ${ }^{22}$ As a general trend, these substitutions become more difficult with the number of (electron withdrawing) substituents attached to the other bridgehead positions. This is due to statistical and/or electronic factors. ${ }^{23,24}$ In particular, electron withdrawing substituents (like carboxy groups) destabilize cationic or radical intermediates leading frequently to drastic reaction conditions for the introduction of additional functionality.

The most obvious retrosynthetic strategies to differentially substituted adamantyl scaffolds $\mathbf{3}$ are depicted in Figure 2. Route I involves the desymmetrization of a tetrasubstituted adamantane derivative $\mathbf{4}$ as a key step. In route II, a trisubstituted intermediate $\mathbf{5}$ is converted to the target structure 3 . Route $\mathrm{C}$ is probably the most obvious choice, because a wide range of mono substituted adamantanes $\mathbf{6}$ is commercially available at low price. However, for the above mentioned reasons, we have not found practical reactions that permit introduction of three appropriate functionalities into various different precursors 6.25

We were therefore focusing on the first two strategies in Figure 2. An essential component of route I is an appropriately (symmetrical) tetrasubstituted adamantane derivative $\mathbf{4}$ and various derivatives of this general structure are known. ${ }^{26-38}$ For our purpose tetracarboxymethyl adamantane $\mathbf{8}$ seemed to be the most appropriate starting material, because we needed carboxylic acids in the target scaffold $\mathbf{1 2}$ (for the conjugation of ligands) and one of the carboxylic acids should be easy to convert to an amine via Curtius reaction. However, none of the known syntheses of $\mathbf{8}^{26,32,35}$ is easily scalable, making $\mathbf{8}$ a precursor of limited value.

We have therefore first tried to develop a more practical synthesis of $\mathbf{8}$. In this context tetraphenyladamantane $7^{28}$ proved to be a good precursor for oxidative degradation. ${ }^{39}$ As depicted in Scheme 1, the conversion of $\mathbf{7}$ to the tetramethylester $\mathbf{8}$ worked, although the yield is not optimal. We decided to tolerate the low yield of these two early steps, because tetraphenyladamantane 7 can easily be generated in large quantities from 1-bromoadamantane as a cheap precursor. Immediate conversion of the intermediate tetracarboxylic acid to its methyl ester $\mathbf{8}$ is advantageous for workup and chromatographic purification of the oxidation product. In addition, the following desymmetrization by a partial ester hydrolysis requires the tetramethyl ester $\mathbf{8}$ as a starting material to give $\mathbf{9}$ in very good yield.

The resulting monocarboxylic acid $\mathbf{9}$ is then converted by a Curtius reaction 40 to the corresponding amine, obtained as its Boc-derivative $\mathbf{1 0}$ after reflux in $t$ - $\mathrm{BuOH}$. The Boc-group is cleaved subsequently with TFA to give the free amine $\mathbf{1 1}$ in good yield. This three-step procedure gave much better yields than the direct acidic hydrolysis of the intermediate isocyanate with water (in the latter case partial hydrolysis of the ester groups was observed).

For later conjugation of this sterically hindered amine to bulky effector molecules, we introduced an Ahx-spacer (6-aminohexanoic acid) at this stage with HATU coupling to give the trimethylester $\mathbf{1 2}$ as an orthogonally protected scaffold, ready for conjugation of ligands and effector molecules. 
An alternative procedure for the synthesis of scaffolds 2 is depicted in Scheme 2. This approach is following the general route II (Figure 2) and does thus require the activation of a relatively unreactive $\mathrm{CH}$-bond in a trisubstituted adamantane for introduction of the last substituent. As mentioned above, the three substituents A in intermediate $\mathbf{5}$ have to be selected carefully, because any electron withdrawing substituent (like the desired carboxyl group) would deactivate the adamantane nucleus for a fourth bridgehead substitution.

Phenyl rings were again found to be excellent substitutes for the carboxyl groups in the target compound 18 and we started with known triphenyladamantane $13 .{ }^{28}$ Like tetraphenyladamantane $\mathbf{7}$, this compound can be easily prepared from cheap 1bromoadamantane in one step via Friedel-Crafts chemistry.

We decided to introduce the fourth substituent to 13 via bromination assuming that the resulting bromide 14 would be a reasonable substrate for a radical addition to acrylonitrile. Among many methods known for the bromination of adamantane bridgeheads, ${ }^{22}$ only one proved to be compatible with our strategy. The mild phase transfer catalyzed protocol developed by Schreiner and coworker ${ }^{41}$ gave bromide $\mathbf{1 4}$ in good yield. This reaction is without precedence for highly substituted adamantanes like $\mathbf{1 3}$ and provides, for the first time, an easy access to tetrahedrally substituted derivatives like 14-18.

After installation of the bromine in $\mathbf{1 4}$, radical addition to acrylonitrile ${ }^{42}$ was achieved in quantitative yield. The resulting cyano compound $\mathbf{1 5}$ was then submitted to an oxidative degradation of the phenyl rings with $\mathrm{RuCl}_{3}$ and $\mathrm{H}_{5} \mathrm{IO}_{6}$ to give the tricarboxylic acid 16. The cyano group was then reduced with hydrogen and $\mathrm{PtO}_{2}$ to give the amine 17 which was Bocprotected in a final step to give the target compound $\mathbf{1 8}$ with a propionyl-spaced amine function for conjugation of effectors and three carboxylic acids for attachment of ligands. It should be noted that no chromatography is necessary for purification of compounds 13-18 because all of them can easily be purified by crystallization.

\section{Summary and Conclusion}

In summary, we report efficient syntheses of new adamantane scaffolds. Both routes are short and give the target compounds $\mathbf{1 2}$ and $\mathbf{1 8}$ in good yields. These scaffolds have been designed to orient three carboxylic acids in a strictly defined tripodal geometry for the conjugation of cell surface binders. In addition, a primary amine allows the conjugation of the scaffold to an effector molecule which is pointing away from the ligands and is therefore unlikely to interfere with the binding process. We are currently evaluating the potential of these scaffolds for various multivalent ligand receptor interactions. It should be noted that our scaffolds are providing a strictly defined tripodal recognition motif (for surfaces) in combination with a fourth binding motif with all four functionalities easily addressable by standard conjugation techniques. Unlike other systems of that sort, ${ }^{21}$ no rigidifying (hydrophobic) aromatic spacers are needed, making them a particularly interesting choice for applications in polar media. We suggest that our scaffolds might be of general use as rigid tetravalent building blocks for applications in organic chemistry 43 and material science. 44

\section{Experimental Section}

\section{3,5,7-Tricarboxymethyladamantane-1-carboxylic acid 9}

$1 \mathrm{~N}$ solution of potassium hydroxide $(0.01 \mathrm{~mL}, 0.01 \mathrm{mmol})$ was added to a solution of $1,3,5,7$ tetracarboxymethyladamantane $8(3.68 \mathrm{mg}, 0.01 \mathrm{mmol})$ in $2 \mathrm{~mL}$ of acetonitrile/methanol/water (3:2:5). The reaction mixture was stirred for 3 hours and the completion of the reaction was followed by thin layer chromatography. Solvents were removed in vacuo and the aqueous solution was washed with dichloromethane $(3 \times 5 \mathrm{~mL})$. The aqueous layer was acidified with 
$1 \mathrm{~N} \mathrm{HCl}$ and extracted with dichloromethane $(3 \times 5 \mathrm{~mL})$. The combined extracts were dried over $\mathrm{Na}_{2} \mathrm{SO}_{4}$ and solvent was removed in vacuo to give $3.1 \mathrm{mg}$ of 9 as white crystals (90\%). ${ }^{1} \mathrm{H}-\mathrm{NMR}\left(\mathrm{CDCl}_{3}, 600 \mathrm{MHz}\right): \delta 3.70(\mathrm{~s}, 9 \mathrm{H}), 2.02(\mathrm{~s}, 6 \mathrm{H}), 2.03(\mathrm{~s}, 6 \mathrm{H}) ;{ }^{13} \mathrm{C}-\mathrm{NMR}$ $\left(\mathrm{CDCl}_{3}, 125 \mathrm{MHz}\right): \delta 181.4,175.6,52.4,42.0,41.8,38.7,38.5$; MS (ESI) [M-H]": 353.4; HRMS (EI) calcd for $\mathrm{C}_{17} \mathrm{H}_{22} \mathrm{O}_{8}[\mathrm{M}]^{+}: 354.1315$. Found: 354.1312 .

\section{7-Amino-1,3,5-tricarboxymethyladamantane 11}

DPPA $(0.063 \mathrm{~mL}, 0.29 \mathrm{mmol})$ and triethylamine $(0.04 \mathrm{~mL}, 0.29 \mathrm{mmol})$ were added to a solution of 3,5,7-tricarboxymethyladamantane-1-carboxylic acid $9(86 \mathrm{mg}, 0.24 \mathrm{mmol})$ dissolved in dichloromethane $(2 \mathrm{~mL})$. The reaction mixture was stirred for 1 hour and the completion of the reaction was followed by TLC. An additional $10 \mathrm{~mL}$ of dichloromethane was added and the reaction mixture was washed with water $(3 \times 10 \mathrm{~mL})$, saturated $\mathrm{NaHCO}_{3}$ solution $(3 \times 10 \mathrm{~mL})$, saturated $\mathrm{NaCl}(3 \times 10 \mathrm{~mL})$ and dried over $\mathrm{Na}_{2} \mathrm{SO}_{4}$. Dichloromethane was removed in vacuo and $t-\mathrm{BuOH}(50 \mathrm{~mL})$ was added. The reaction mixture was refluxed under nitrogen atmosphere for 5 hours. Excess of $t$ - $\mathrm{BuOH}$ was removed in vacuo and the colorless residue (10) was treated with a solution of $50 \%$ of TFA in dichloromethane $(5 \mathrm{~mL})$. The reaction mixture was stirred at room temperature for one hour. The solvent was removed in vacuo and the white residue was purified by column chromatography (silica gel, EtOAc / hexane, $6: 4, R_{f}=0.78$ ) to give $65 \mathrm{mg}$ of $\mathbf{1 1}$ as a colorless solid (83\%). ${ }^{1} \mathrm{H}-\mathrm{NMR}\left(\mathrm{CDCl}_{3}, 600 \mathrm{MHz}\right): \delta 3.65(\mathrm{~s}, 9 \mathrm{H}), 2.03-1.89$ (m, $12 \mathrm{H}) ;{ }^{13} \mathrm{C}-\mathrm{NMR}\left(\mathrm{CDCl}_{3}, 125 \mathrm{MHz}\right): \delta 175.9,52.4,52.143 .2,42.0,38.8$; HRMS (ESI) calcd. for $\mathrm{C}_{16} \mathrm{H}_{24} \mathrm{NO}_{6}[\mathrm{M}+\mathrm{H}]$ : 326.1604 . Found: 326.1598 .

\section{1-Bromo-3,5,7-triphenyladamantane 14}

To a solution of 1,3,5-triphenyladamantane $13(0.20 \mathrm{~g}, 0.55 \mathrm{mmol})$, tetrabrommethane $(0.73$ $\mathrm{g}, 2.2 \mathrm{mmol})$ and tetrabutylammoniumbromide $(0.02 \mathrm{~g}, 0.06 \mathrm{mmol})$ in $5 \mathrm{~mL}$ flourobenzene were added $3 \mathrm{~mL} \mathrm{NaOH}$ (wt 50\%) and the resulting reaction mixture was heated to $75{ }^{\circ} \mathrm{C}$ for $24 \mathrm{~h}$. The solvent was evaporated in vacuo; the crude product was suspended in water and extracted three times with each $20 \mathrm{~mL}$ dichloromethane. The combined organic layers were dried over $\mathrm{Na}_{2} \mathrm{SO}_{4}$, filtered and the solvent was evaporated in vacuo to give the bromide 14 . After Crystallization from hexane/ethyl acetate (1:1), $0.26 \mathrm{~g}(0.49 \mathrm{mmol} ; 89 \%)$ of $\mathbf{1 4}$ were isolated as a yellow solid. ${ }^{1} \mathrm{H}-\mathrm{NMR}\left(\mathrm{CDCl}_{3}, 400 \mathrm{MHz}\right): \delta$ 7.23-7.35 $(\mathrm{m}, 15 \mathrm{H}), 2.62(\mathrm{~s}, 6 \mathrm{H})$, $2.17\left(\mathrm{~d}, 3 \mathrm{H},{ }^{2} J=13.4 \mathrm{~Hz}\right), 2.14\left(\mathrm{~d}, 3 \mathrm{H},{ }^{2} J=13.4 \mathrm{~Hz}\right) ;{ }^{13} \mathrm{C}-\mathrm{NMR}\left(\mathrm{CDCl}_{3}, 100 \mathrm{MHz}\right): \delta 147.8$, 128.7, 126.7, 125.0, 65.2, 52.8, 46.7, 42.3; HRMS (EI) calcd. for $\mathrm{C}_{28} \mathrm{H}_{27} \mathrm{Br}$; MS [M] ${ }^{+}$: 442.1296. Found: 442.1297.

\section{1,3,5-Triphenyl-7-(2-cyanoethyl)-adamantane 15}

A solution of 1-bromo-3,5,7-triphenyladamantane $14(0.50 \mathrm{~g}, 1.13 \mathrm{mmol})$, acrylonitrile ( 0.18 $\mathrm{g}, 3.39 \mathrm{mmol})$, tributylstannane $(0.65 \mathrm{~g}, 2.26 \mathrm{mmol})$ and AIBN $(19 \mathrm{mg}, 0.113 \mathrm{mmol})$ in $10 \mathrm{ml}$ toluene was heated to reflux for $6 \mathrm{~h}$. Ethyl acetate und $1 \mathrm{M}$ aqueous $\mathrm{NH}_{3}$ solution were added and the separated organic phase was washed with $1 \mathrm{M}$ aqueous $\mathrm{NH}_{3}$ solution and water, dried over $\mathrm{Na}_{2} \mathrm{SO}_{4}$, filtered and the solvent was evaporated in vacuo. The crude product was purified by filtration over silica (byproducts were eluted with hexane/ethyl acetate 2:1; product with ethyl acetate) to give $0.47 \mathrm{~g}$ of $\mathbf{1 5}$ (1.13 mmol; quant). ${ }^{1} \mathrm{H}-\mathrm{NMR}\left(\mathrm{CDCl}_{3}, 400 \mathrm{MHz}\right): 7.21-7.44$ $(\mathrm{m}, 15 \mathrm{H}), 2.42\left(\mathrm{t}, 2 \mathrm{H},{ }^{3} \mathrm{~J}=8.1 \mathrm{~Hz}\right), 2.12\left(\mathrm{~d}, 3 \mathrm{H},{ }^{2} J=12.3 \mathrm{~Hz}\right), 2.07\left(\mathrm{~d}, 3 \mathrm{H},{ }^{2} J=12.3 \mathrm{~Hz}\right), 1.80$ (t, $\left.2 \mathrm{H},{ }^{3} \mathrm{~J}=8.1 \mathrm{~Hz}\right), 1.75(\mathrm{~s}, 6 \mathrm{H}) ;{ }^{13} \mathrm{C}-\mathrm{NMR}\left(\mathrm{CDCl}_{3}, 100 \mathrm{MHz}\right): 149.0,128.6,126.4,125.1$, 12.5, 47.5, 46.0, 39.1, 39.0, 35.3, 11.5; HRMS (EI) calcd. for $\mathrm{C}_{31} \mathrm{H}_{31} \mathrm{~N}[\mathrm{M}]^{+}:$417.2457. Found: 417.2452.

\section{1,3,5-Tricarboxy-7-(2-cyanoethyl)-adamantane 16}

A solution of $15(550 \mathrm{mg}, 1.3 \mathrm{mmol})$ and $\mathrm{H}_{5} \mathrm{IO}_{6}(12.6 \mathrm{~g}, 55 \mathrm{mmol})$ in $50 \mathrm{ml} \mathrm{CCl} / \mathrm{MeCN} /$ $\mathrm{H}_{2} \mathrm{O}(3: 2: 3)$ was cooled to $0{ }^{\circ} \mathrm{C}$ and $\mathrm{RuCl}_{3} \times 3 \mathrm{H}_{2} \mathrm{O}(69 \mathrm{mg}, 0.3 \mathrm{mmol})$ was added. After stirring 
for $2 \mathrm{~h}$ at $0{ }^{\circ} \mathrm{C}$ and $40 \mathrm{~h}$ at $\mathrm{rt}$, the resulting reaction mixture was poured on ice and excess oxidant was destroyed by $\mathrm{Na}_{2} \mathrm{SO}_{3}$ addition. The aqueous layer was washed with ethyl acetate, acidified with $2 \mathrm{~N} \mathrm{HCl}(\mathrm{pH} 1)$ and extracted three times with ethyl acetate. The combined organic layers were dried over $\mathrm{Na}_{2} \mathrm{SO}_{4}$, filtered and the solvent was evaporated in vacuo to give $360 \mathrm{mg}$ of $\mathbf{1 6}(1.1 \mathrm{mmol} ; 85 \%)$. ${ }^{1} \mathrm{H}-\mathrm{NMR}$ (DMSO-d $\left.\mathrm{d}_{6}, 400 \mathrm{MHz}\right): \delta 12.3(\mathrm{br} \mathrm{s}, 3 \mathrm{H}), 2.46$ $\left(\mathrm{t}, 2 \mathrm{H},{ }^{3} \mathrm{~J}=7.9 \mathrm{~Hz}\right), 1.79\left(\mathrm{~d}, 3 \mathrm{H},{ }^{2} J=13.7 \mathrm{~Hz}\right), 1.72\left(\mathrm{~d}, 3 \mathrm{H},{ }^{2} J=13.7 \mathrm{~Hz}\right), 1.53\left(\mathrm{t}, 2 \mathrm{H},{ }^{3} J=\right.$ $7.9 \mathrm{~Hz}$ ), 1.48 (s, 6H); ${ }^{13} \mathrm{C}-\mathrm{NMR}$ (DMSO-d 6 , $100 \mathrm{MHz}$ ): $\delta$ 177.1, 121.4, 41.1, 40.7, 40.3, 36.8, 33.3, 10.3; $\mathrm{C}_{16} \mathrm{H}_{19} \mathrm{NO}_{6}$ calcd. C 59.81; H 5.96; $\mathrm{N}$ 4.36; found C 59.86; $\mathrm{H}$ 6.00; $\mathrm{N}$ 4.33; HRMS (EI) calcd. for $\mathrm{C}_{16} \mathrm{H}_{19} \mathrm{NO}_{6}[\mathrm{M}]^{+}:$321.1212. Found: 321.1208.

\section{1,3,5-Tricarboxy-7-(3-aminopropyl)-adamantane hydrochloride 17}

A solution of nitrile $16(30 \mathrm{mg}, 0.093 \mathrm{mmol})$ and $\mathrm{PtO}_{2}(4.2 \mathrm{mg}, 0.019 \mathrm{mmol})$ in $10 \mathrm{ml}$ glacial acetic acid/conc. $\mathrm{HCl}(10: 1)$ was hydrogenated (30 bar, rt) for $48 \mathrm{~h}$. The resulting mixture was filtered and the solvent was evaporated in vacuo. The crude product was dissolved in water and washed two times with ethyl acetate. After evaporation of water in vacuo, $33 \mathrm{mg}(0.091$ mmol; 98\%) of $\mathbf{1 7}$ were isolated as colorless crystals. ${ }^{1} \mathrm{H}-\mathrm{NMR}\left(\mathrm{D}_{2} \mathrm{O}, 400 \mathrm{MHz}\right): \delta 2.96(\mathrm{t}$, $\left.2 \mathrm{H},{ }^{3} \mathrm{~J}=7.4 \mathrm{~Hz}\right), 1.94(\mathrm{~s}, 6 \mathrm{H}), 1.64-1.69(\mathrm{~m}, 2 \mathrm{H}), 1.61(\mathrm{~s}, 6 \mathrm{H}), 1.30-1.34(\mathrm{~m}, 2 \mathrm{H}) ;{ }^{13} \mathrm{C}-\mathrm{NMR}$ $\left(\mathrm{D}_{2} \mathrm{O}, 100 \mathrm{MHz}\right): \delta 180.8,41.9,40.9,40.0,38.5,38.0,33.0,20.2$; MS (ESI) [M-Cl] ${ }^{+}: 326.4$; HRMS (EI) calcd. for $\mathrm{C}_{16} \mathrm{H}_{24} \mathrm{NO}_{6}[\mathrm{M}-\mathrm{Cl}]^{+}:$326.1604. Found: 326.1602 .

\section{Supplementary Material}

Refer to Web version on PubMed Central for supplementary material.

\section{Acknowlegdement}

We gratefully acknowledge support from the Deutsche Forschungsgemeinschaft (MA 2529/3). We thank Barbara L. Clough for editing and Eugenia Trabucchi for administrative assistance. This research was supported by NIH grant R01-CA-115296 and grants from the Ellison Foundation and Lewis Family Fund to JVF.

\section{REFERENCES}

(1). Mammen M, Chio S-K, Whitesides GM. Angew. Chem., Int. Ed 1998;37:2755-2794.

(2). Carlson C, Mowery P, Owen R, Dykhuizen E, Kiessling L. ACS Chem. Biol 2007;2:119-127. [PubMed: 17291050]

(3). Wittmann V, Seeberger S. Angew. Chem., Int. Ed. Engl 2004;43:900-903. [PubMed: 14767971]

(4). Griffin JH, Linsell MS, Nodwell MB, Chen Q, Pace JL, Quast KL, Krause KM, Farrington L, Wu TX, Higgins DL, Jenkins TE, Christensen BG, Judice JK. J. Am. Chem. Soc 2003;125:6517-6531. [PubMed: 12785792]

(5). Lundquist JJ, Toone EJ. Chem. Rev 2002;102:555-578. [PubMed: 11841254]

(6). Lindhorst TK. Top. Curr. Chem 2002;218:201-235.

(7). Wright D, Usher L. Curr. Org. Chem 2001;5:1107-1131.

(8). Thumshirn G, Hersel U, Goodman SL, Kessler H. Chem. --Eur. J 2003;9:2717-2725.

(9). Fournel S, Wieckowski S, Sun W, Trouche N, Dumortier H, Bianco A, Chaloin O, Habib M, Peter JC, Schneider P, Vray B, Toes RE, Offringa R, Melief CJ, Hoebeke J, Guichard G. Nat. Chem. Biol 2005;1:377-382. [PubMed: 16370373]

(10). Kitov PI, Bundle DR. J. Am. Chem. Soc 2003;125:16271-16284. [PubMed: 14692768]

(11). Gestwicki JE, Strong LE, Kiessling LL. Chem. Biol 2000;7:583-591. [PubMed: 11048949]

(12). Cairo CW, Gestwicki JE, Kanai M, Kiessling LL. J. Am. Chem. Soc 2002;124:1615-1619. [PubMed: 11853434]

(13). Gestwicki JE, Cairo CW, Strong LE, Oetjen KA, Kiessling LL. J. Am. Chem. Soc 2002;124:1492214933. [PubMed: 12475334]

(14). Gordon EJ, Gestwicki JE, Strong LE, Kiessling LL. Chem. Biol 2000;7:9-16. [PubMed: 10662681] 
(15). Merritt EA, Zhang Z, Pickens JC, Ahn M, Hol WG, Fan E. J. Am. Chem. Soc 2002;124:8818-8824. [PubMed: 12137534]

(16). Roy R, Page D, Perez SF, Bencomo VV. Glycoconjugate J 1998;15:251-263.

(17). Haag R, Kratz F. Angew. Chem., Int. Ed. Engl 2006;45:1198-1215. [PubMed: 16444775]

(18). Maison W, Frangioni JV, Pannier N. Org. Lett 2004;6:4567-4569. [PubMed: 15548077]

(19). Humblet V, Lapidus R, Williams LR, Tsukamoto T, Rojas C, Majer P, Hin B, Ohnishi S, De Grand AM, Zaheer A, Renze JT, Nakayama A, Slusher BS, Frangioni JV. Mol. Imaging 2005;4:448-462. [PubMed: 16285907]

(20). Misra P, Humblet V, Pannier N, Maison W, Frangioni JV. J. Nucl. Med 2007;48:1379-1389. [PubMed: 17631555]

(21)a). Li Q, Rukavishnikov AV, Petukhov PA, Zaikova TO, Jin C, Keana JFW. J. Org. Chem 2003;68:4862-4869. [PubMed: 12790592] b) Li Q, Jin C, Petukhov PA, Rukavishnikov AV, Zaikova TO, Phadke A, LaMunyon DH, Lee MD, Keana JF. J. Org. Chem 2004;69:1010-1019. [PubMed: 14961648]

(22). Moiseev IK, Makarova NV, Zemtsova MN. Russ. Chem. Rev 1999;68:1001-1020.Fokin AA, Shubina TE, Gunchenko PA, Isaev SD, Yurchenko AG, Schreiner PR. J. Am. Chem. Soc 2002;124:10718-10727. [PubMed: 12207527]For a recent mechanistic analysis of these reactions see

(23). Fort RC, Schleyer P. v. R. Chem. Rev 1964;64:277-300.

(24). Saunders M, Jimenez-Vazquez HA. Chem. Rev 1991;91:375-397.

(25). We have tried different reactions for bridgehead functionalization such as arylations, halogenations and Koch-Haaf-type reactions with different substrates $6\left(\mathrm{~B}=\mathrm{NHR}, \mathrm{OH}, \mathrm{CN}, \mathrm{CO}_{2} \mathrm{H}, \mathrm{CH}_{2} \mathrm{NH}_{3}\right.$, $\left.\mathrm{CH}_{2} \mathrm{CN}, \mathrm{CH}_{2} \mathrm{CO}_{2} \mathrm{H},\left(\mathrm{CH}_{2}\right)_{3} \mathrm{NH}_{2},\left(\mathrm{CH}_{2}\right)_{3} \mathrm{CN},\left(\mathrm{CH}_{2}\right)_{3} \mathrm{CO}_{2} \mathrm{H}\right)$ and achieved only mono- or disubstitution

(26). Landa S, Kamycek Z. Collect. Czech. Chem. Commun 1959;24:4004-4009.

(27). Stetter H, Wulff C. Chem. Ber 1960;93:1366-1371.

(28). Newman H. Synthesis 1972:692-693.

(29). Sollott GP, Gilbert EE. J. Org. Chem 1980;45:5405-5408.

(30). Naemura K, Hokura Y, Nakazaki M. Tetrahedron 1986;42:1763-1768.

(31). Reichert VR, Mathias LJ. Macromolecules 1994;27:7015-7023.

(32). Bashir-Hashemi A, Li J, Gelber N. Tetrahedron Lett 1995;36:1233-1236.

(33). Li Q, Rukavishnikov AV, Petukhov PA, Zaikova TO, Jin C, Keana JFW. J. Org. Chem 2003;68:4862-4869. [PubMed: 12790592]

(34). Dave PR, Duddu R, Yang K, Damavarapu R, Gelber N, Surapaneni R, Gilardi R. Tetrahedron Lett 2004;45:2159-2162.

(35). Lee GS, Bashara JN, Sabih G, Oganesyan A, Godjoian G, Duong HM, Marinez ER, Gutierrez CG. Org. Lett 2004;6:1705-1707. [PubMed: 15151394]

(36). Kozhushkov SI, Yufit DS, Boese R, Blaeser D, Schreiner PR, de Meijere A. Eur. J. Org. Chem 2005:1409-1415.

(37). Menger FM, Migulin VA. J. Org. Chem 1999;64:8916-8921. [PubMed: 11674798]

(38). Martin VV, Alferiev IS, Weis AL. Tetrahedron Lett 1999;40:223-226.

(39). Carlsen PHJ, Katsuki T, Martin VS, Sharpless KB. J. Org. Chem 1981;46:3936-3938.

(40). Smith PAS. Org. React. (N.Y.) 1946;3:337.

(41). Fokin AA, Schreiner PR. Adv. Syn. Cat 2003;345:1035-1052.

(42). Ohno M, Ishizaki K, Eguchi S. J. Org. Chem 1988;53:1285-1288.

(43). Maison W, Frangioni JV. Angew. Chem., Int. Ed. Engl 2003;42:4726-4728. [PubMed: 14562338]

(44). Li Q, Jin C, Petukhov PA, Rukavishnikov AV, Zaikova TO, Phadke A, LaMunyon DH, Lee MD, Keana JF. J. Org. Chem 2004;69:1010-1019. [PubMed: 14961648] 


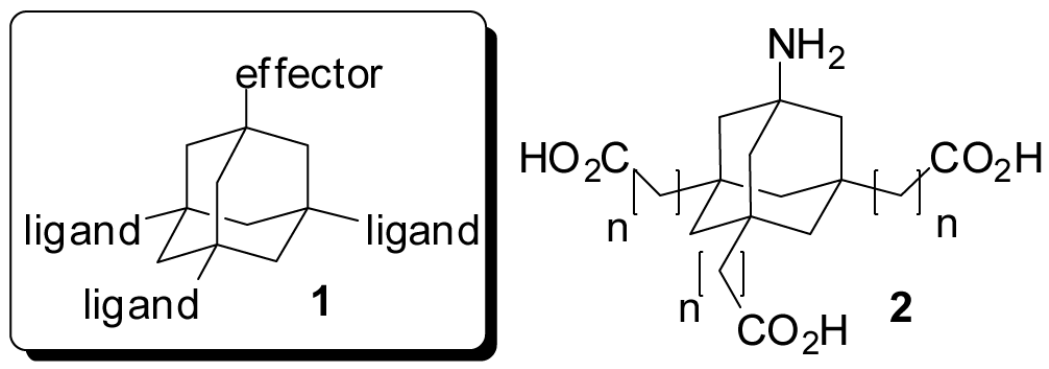

Figure 1.

Schematic drawing of modular multivalent ligands $\mathbf{1}$ and suitable scaffolds $\mathbf{2}$. 

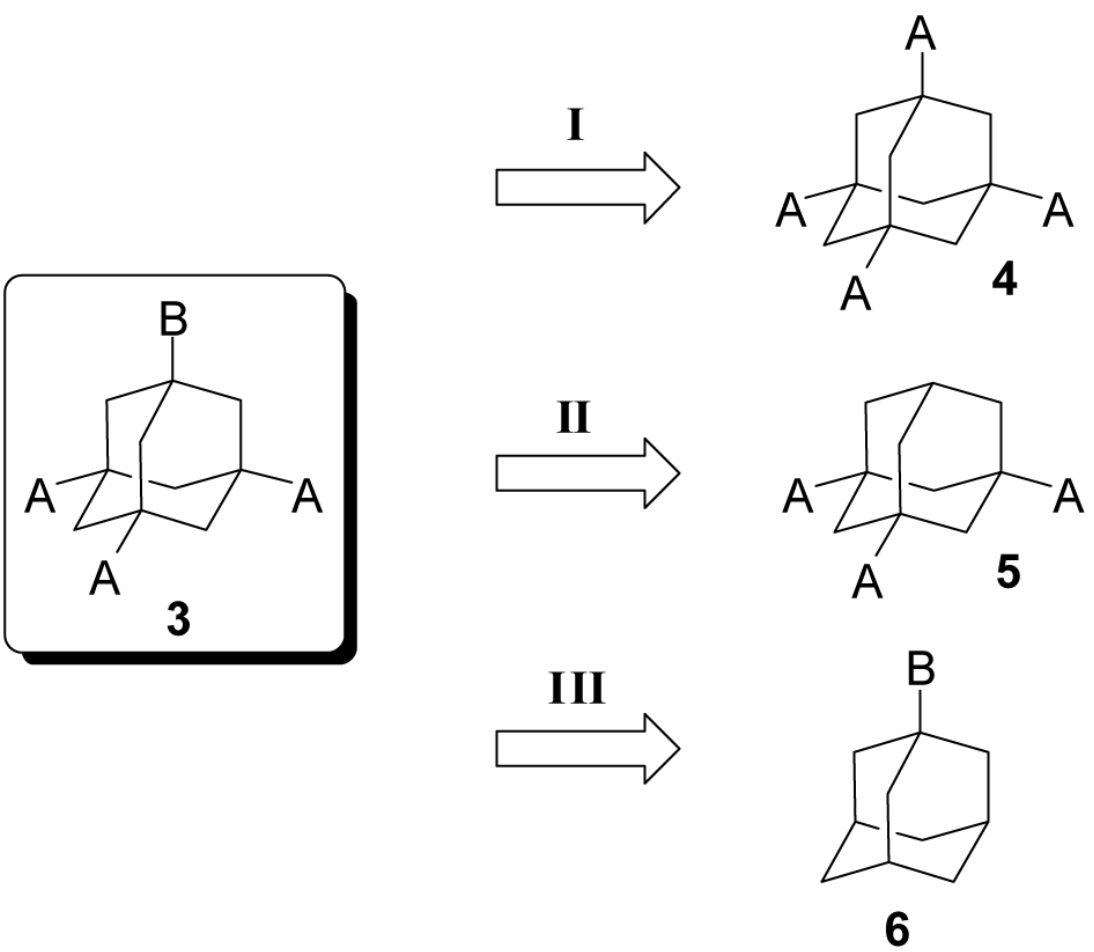

Figure 2.

Retrosynthetic analysis of adamantyl scaffolds $\mathbf{3}$. 


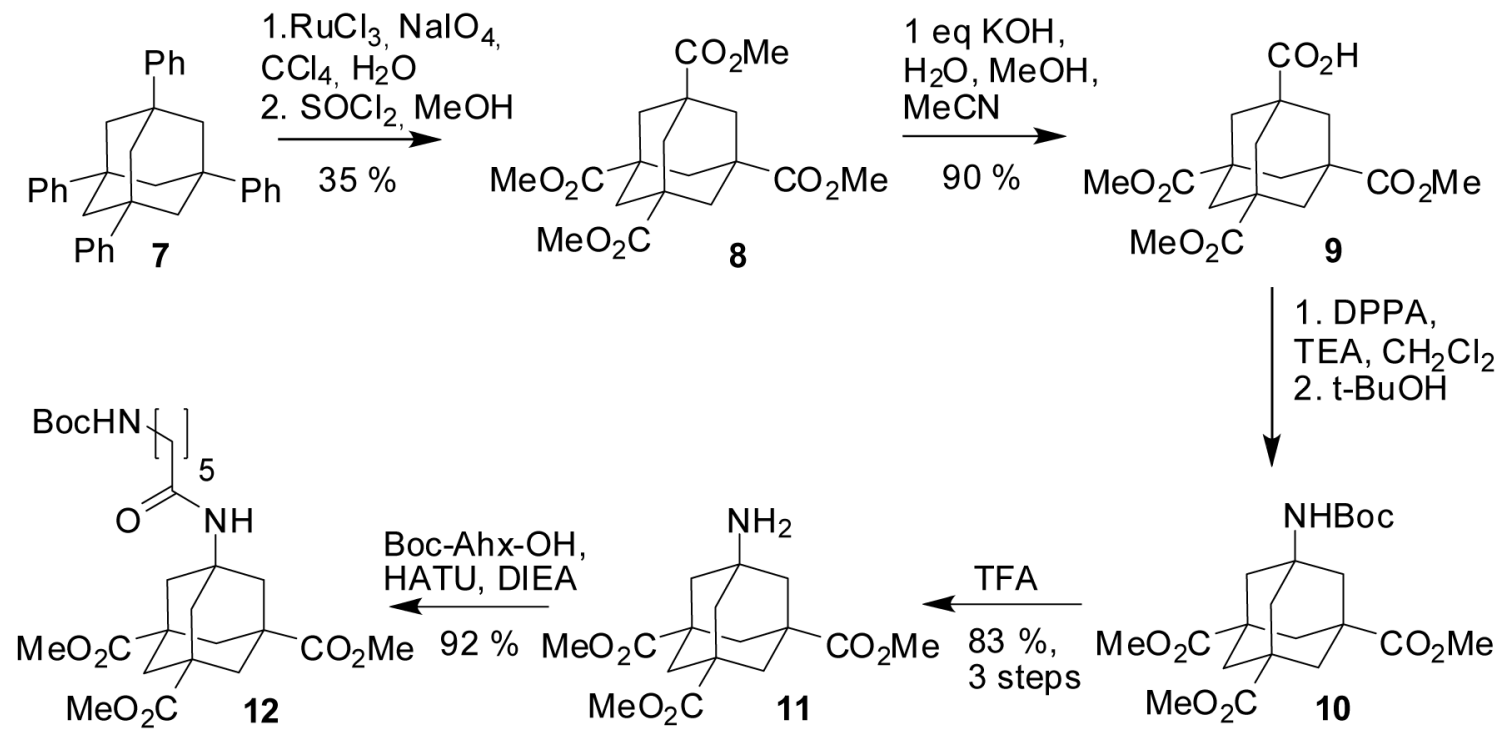

Scheme 1.

Synthesis of rigid adamantane scaffold 12 following general route I (Figure 2). 


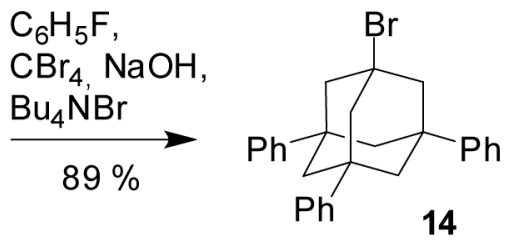

13
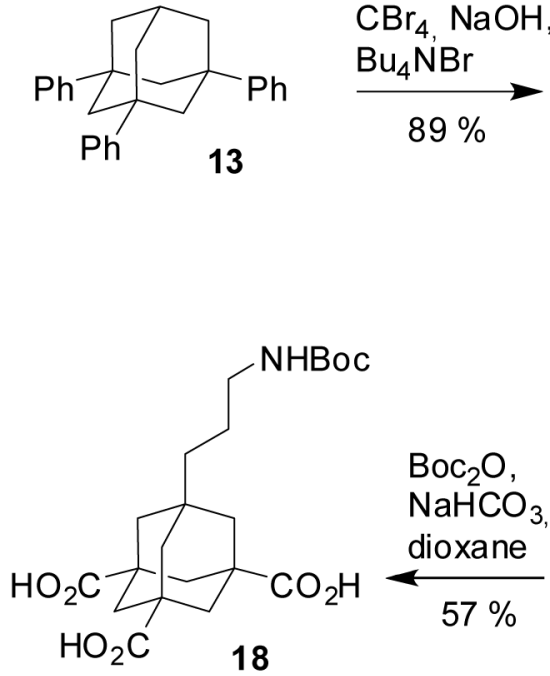
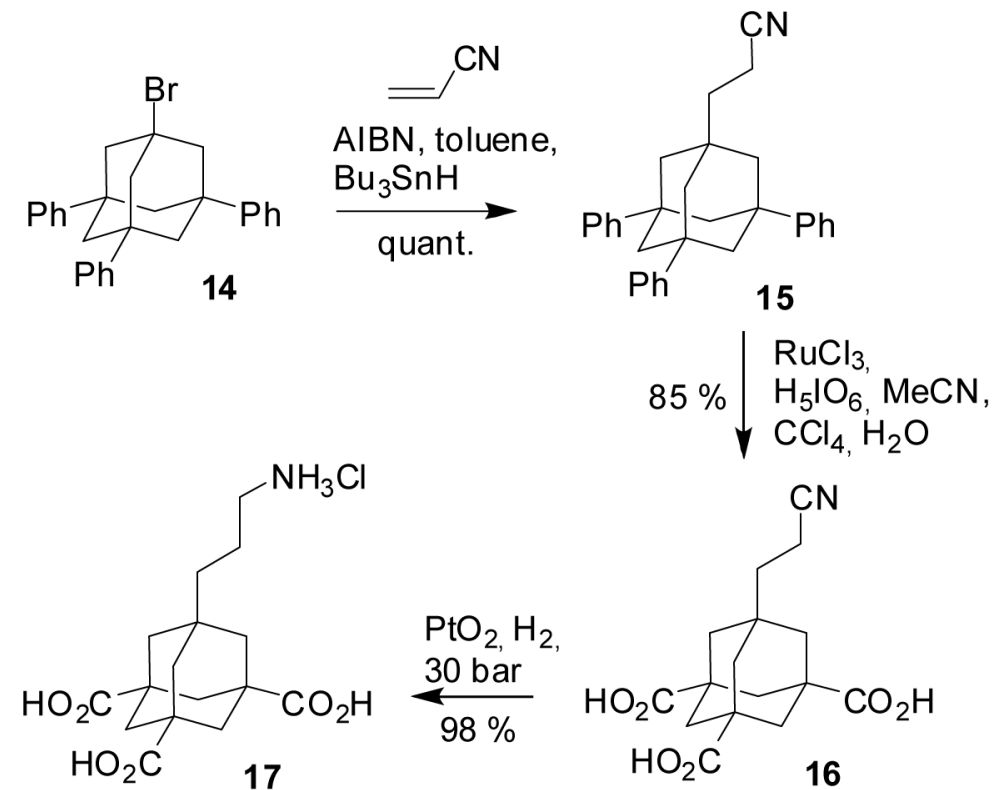

\section{Scheme 2.}

Synthesis of rigid adamantane scaffold $\mathbf{1 8}$ following general route II (Figure 2). 